\title{
Determination of Molecular Interactions Between Fraser's Photinia (Photinia X Fraseri) and Its Endophytic Bacterium PGB_Invit
}

Nil TÜRKÖLMEZ

Gebze Technical University: Gebze Teknik Universitesi

Merve KARAKAYA

Gebze Technical University: Gebze Teknik Universitesi

Hamit Ekinci

Gebze Technical University: Gebze Teknik Universitesi

Stuart J. LUCAS

Sabanci University: Sabanci Universitesi

Özlem AKKAYA

Gebze Technical University: Gebze Teknik Universitesi

Mine Gül Şeker

Gebze Technical University: Gebze Teknik Universitesi

Ceyhun KAYIHAN

Başkent Üniversitesi: Baskent Universitesi

Yelda Ozden ( $\nabla$ yelda75@yahoo.com)

Gebze Teknik Universitesi https://orcid.org/0000-0002-9799-3648

\section{Research Article}

Keywords: Endophytic bacteria, Plant Growth Promoting Bacteria, Fraser's Photinia, Micropropagation, RNA-seq

Posted Date: February 11th, 2022

DOI: https://doi.org/10.21203/rs.3.rs-1288819/v1

License: @ (i) This work is licensed under a Creative Commons Attribution 4.0 International License. Read Full License 


\section{Abstract}

An endophytic beneficial bacterium, was isolated and characterized from in vitro grown microshoots of Fraser's Photinia in our previous studies. This bacterium, nominated as PGB_invit (Pseudorhodoplanes sp.), has ability to fix nitrogen and produce plant growth promoting regulators such as indole acetic acid and gibberellic acid. Probably because of all of these features, this specific bacterium promotes in vitro proliferation of Fraser's Photinia microshoots and enables microshoots to be conserved at $25^{\circ} \mathrm{C}$ for up to 16 months without requiring periodic subculture. Due to its beneficial influence on growth of Fraser's Photinia, it is aimed to identify physiological, biochemical and molecular influences of this bacterium together with determination of its the localization in plant tissues. Our results showed that inoculation with PGB_invit bacteria $\left(10^{6} \mathrm{cfu} / \mathrm{ml}\right)$ has increased chlorophyll content without causing any severe oxidative stress. Moreover, the genes [gene bank ID XP_008352422.1 (predicted “MID1-Complementing Activity 1"), PWZ54828.1 (Ubiquitin conjugating enzyme E2), XP_028948963.1 (predicted “E3 ubiquitin-protein ligase RHA1B-like”), XP_008339965.2 (uncharacterized protein), XP_028948163.1 (4-coumarate-CoA ligaselike 9), and XP_028953023 (methionine aminopeptidase 2B-like)] which are upregulated or downregulated after inoculation of this bacterium according to RNA-seq analysis, were also confirmed with qRT-PCR in order to understand its molecular interaction with its host.

\section{Introduction}

Plant-microbe interactions such as competition, commensalism, mutualism, and parasitism are a vital part of our terrestrial ecosystem (Wu et al., 2009). Hence, a wide variety of microorganisms such as bacteria, fungi, actinomycetes, algae, and protozoa can be found in soil (Kumar, 2016) and a great deal of research has been performed on Plant Growth-Promoting Rhizobacteria (PGPR) among them.

PGPRs are non-pathogenic for plants and strongly increase the yield of the plant with their beneficial effects by colonizing on the surface or in internal tissues of the plant roots (Babalola, 2010; Kargapolova et al., 2020). Among PGPRs, endophytic bacteria, which are colonize internal tissues, communicate and interact with the plant more efficiently than rhizospheric bacteria and in a result of this, their beneficial effect will be more efficient (Hernández-Soberano et al., 2020). These effects can happen through one or more mechanisms such as production of phytohormones, metabolites and siderophores, fixation of nitrogen, biocontrol of root zone pathogens, uptake of nutrients or stimulation of plants to produce these molecules. Many endophytic strains can also regulate plant immunity responses and developmental processes such as cell division, cell elongation, cell differentiation by producing and/or degrading a kind of auxin, i.e., indole acetic acid (IAA) (Sturz et al., 2000; Khan et al., 2020).

As a result of all these features, they are considered as a way to reduce the use of chemical fertilizers for plant growth (Wu et al., 2009). It is well known that excessive use of chemical fertilizers not only deteriorates soil quality and fertility, but also it negatively affects fertile lands that can be used for agriculture (Chauhan et al., 2022). For this reason, interest in studies on this subject has increased in recent years. For instance, Llorente and Larraburu (Llorente and Larraburu, 2013) inoculated Fraser's Photinia with Azospirillum brasilense and observed early rooting of Fraser's Photinia shoots and significant increase in root fresh and dry weights, root surface area, and shoot fresh and dry weights in comparison with controls.

In 2019, Chen and Liu, inoculated soil with Pantoea sp. S32 (phosphate-solubilizing bacterium) and they found that this bacterium converts insoluble forms of phosphorus $(\mathrm{P})$ to accessible forms. In addition to this, they performed a rice seedling experiment with this bacteria at the same time and recorded that there is a significant increase in height, biomass, root growth, and P uptake of rice (Chen and Liu, 2019). Moreover, Adesemoye et al. (2009), reported that, with the use of PGPR strains such as Bacillus amyloliquefaciens IN937a and Bacillus pumilis T4, plant growth, crop yield and flow of nutrients were increased using 75\% of the recommended fertilizer rate. Therefore, it is possible to use PGPRs as biofertilizers in agriculture (Rosenblueth and Martínez-Romero, 2006).

Besides their usage as microbial fertilizers, it is also vital to understand PGPR-plant molecular interactions to reveal out how this beneficial interaction work well in these organisms. Approaches such as transcriptomics (RNA-seq and microarrays etc.) are known as powerful tools to understand bacterial gene functions in the plant microbiome (Nobori et al., 2021). RNA-seq transcriptional profiling, which allows detection of differentially expressed genes involved in the oxidative stress response, plant immunity, production of plant hormones and secondary metabolites, has been utilized in the literature to detect differentially expressed genes profiles of different plant species inoculated with rhizobial strains. Accordingly, distinct transcriptomic responses were evidenced in soybean (Glycine max) after inoculation with rhizobial strains belonging to two different genus, Bradyrhizobium japonicum and Sinorhizobium (Ensifer) fredii (Yuan et al., 2016). Another study compared transcriptomic profiles of Lotus japonicus upon inoculation with compatible rhizobial, non-adapted rhizobial and pathogenic bacterial strains, and revealed that compatible rhizobia did not induce early defense-like responses (Kelly et al., 2018).

In our previous reports, the presence of a unique bacterium, that positively affects plant growth, has been identified during tissue culture studies with Fraser's Photinia (Gül Şeker et al., 2017; Şah et al., 2019). According to phylogenetic analysis, this putatively endophytic bacteria, PGB_invit, is also a PGPR from the Alphaproteobacteria group that has capability to fix nitrogen and produce some plant growth promoting regulators such as indole acetic acid (IAA) and gibberellic acid $\left(\mathrm{GA}_{3}\right)$. The most similar reported species was found to be Pseudorhodoplanes sinuspersici strain C16-RIPI 110 (JX500274.3), isolated from oil contaminated soils in Siri island, Iran, with 16S r-DNA analysis (Tirandaz et al., 2015). Although, there are some similarities like being rod-shaped, staining Gram-negative, being facultatively anaerobic, occurring as small colonies on agar plates, having catalase production and growing optimally $30{ }^{\circ} \mathrm{C}$ and $\mathrm{pH} 7$, they have differences in fatty acid features and carbon sources that they utilize. Moreover, it also determined that $\beta$-polyhydroxybutyrate production and intracellular polyphosphate accumulation occurred in PGB_invit cells. Thus, PGB_invit could be considered as a putatively new species of Pseudorhodoplanes sp.

It has been previously shown that PGB_invit promotes in vitro proliferation of Fraser's Photinia without subculturing for up to 16 months, as well as rooting and acclimatization of in vitro propagated shoots (Şah et al., 2019). However, there are still unsolved questions on, for instance, the optimum bacterial inoculation concentration, incubation time and its location in plants. Moreover, the physiological, biochemical and molecular influences of this bacterium on its host are still unknown to understand the mechanism of this positive interaction. Hence, it is aimed to optimize the beneficial effects of the PGB_invit on 
Fraser's Photinia under in vitro and subsequently in vivo conditions, by performing physiological and biochemical determinations. In addition, molecular interactions between PGB_invit and Fraser's Photinia in in vitro conditions is also investigated by analyzing the changes in gene expression levels with RNAseq and qRT-PCR analysis.

\section{Material \& Methods}

\subsection{PGB_invit Culture}

Mineral-Pepton-Yeast-Extract (MPYE) medium (Davidson et al., 1989) which contains peptone (3g/L), yeast extract (3g/L), $1 \mathrm{M} \mathrm{MgCl} 2(1 \mathrm{ml})$ and $1 \mathrm{M} \mathrm{CaCl} 2$ (1 $\mathrm{ml}$ ) with pH:7.0 were used to promote the growth of PGB_invit at $30^{\circ} \mathrm{C}$. Bacterial culture initially started from $-20^{\circ} \mathrm{C}$ stocks into MPYE broth and bacteria streaked to MPYE agar by sterile loop after 7 days of growth. Following the growth for 7 days in MPYE medium, colonies became apparent and a single colony from this medium inoculated into MPYE broth again and incubated there for 7 more days at $30^{\circ} \mathrm{C}$. This bacteria culture used to inoculate Fraser's Photinia's in vitro tissue culture. Following the adjustment of the turbidity to $0.6 \mathrm{McFarland}$ (approximately $\left.10^{8} \mathrm{cfu} / \mathrm{ml}\right)$, three different serial dilutions $\left(10^{2}, 10^{4}\right.$ and $10^{6} \mathrm{cfu} / \mathrm{ml}$ ) were prepared to find the optimum inoculation concentration.

\subsection{In vitro proliferation of Fraser's Photinia}

Shoots of Fraser's Photinia were provided from Gebze Technical University garden. After surface sterilization of shoots by washing under water for 90 min., $70 \% \mathrm{v} / \mathrm{v}$ EtOH for 10-15 seconds, rinsing with 1.5\% v/v bleach ( $\mathrm{NaOCl}$ ) for 20 minutes, washing 3 times for 10 minutes with sterile distilled water, shoot tips were excised and transferred to fresh QL medium (Quoirin and Lepoivre, 1977) containing $1 \mathrm{mg} / \mathrm{L} \mathrm{BA}$ (proliferation medium). Cultures were incubated in a growth room at $25^{\circ} \mathrm{C}$ under a $16 \mathrm{~h}$ photoperiod of $36 \mu \mathrm{mol} \mathrm{m} \mathrm{m}^{-2} \mathrm{~s}^{-1}$ photosynthetic photon flux provided by cool-white fluorescent lamps. Following their proliferation for four weeks, microshoots subcultured monthly (at least for 3 months) to proliferation medium and then excised shoot tips were used in the inoculation experiments.

\subsection{Determination of the optimum inoculum for PGB_invit}

The turbidity of PGB_invit bacterium in fresh culture medium was adjusted to $0.6 \mathrm{McFarland}$ at $\mathrm{OD}_{600}$ in physiological saline and from that, three different serial dilutions $\left(10^{2}, 10^{4}\right.$ and $\left.10^{6} \mathrm{cfu} / \mathrm{ml}\right)$ were prepared. These dilutions were spread on QL medium by Drigalski spatula (100 $\mu$ l for each). Non-PGB_invittreated shoot tips served as a control group and they were inoculated only with physiological saline solution (PSS) to reveal out its possible effect on growth of plants. Moreover, three groups were prepared by inoculation of plants with bacterium in three concentration (as mentioned above) which are inactivated in $95^{\circ} \mathrm{C}$ for 20 minutes.

All groups of plants (8 groups as total) were cultured in in vitro proliferation conditions explained before in different time periods, 30,45 and 60 days without subculturing. Subculturing was not carried out in those trails as we previously reported that PGB_invit has capability to support in vitro shoot growth in Fraser's Photinia without subculturing up to 36 months (Şah et al., 2017). The results are evaluated as proliferation percentage (\%), shoot/explant rate and shoot length in all plant groups. According to the results, the optimum inoculation concentration and the optimum in vitro proliferation time period determined as the group of inoculated with $10^{6} \mathrm{cfu} / \mathrm{ml}$ active PGB_invit bacteria and 60 days for best development of plants. Therefore, we performed our experiments further to understand the effects of plant-bacteria interaction on physiological, biochemical and molecular levels, on shoot growth together with rooting and acclimatization.

\subsection{Determination of PGB_invit's Effect On Amount of Photosynthetic Pigments}

PGB_invit's effect on photosynthetic pigments concentration (chlorophyll a, chlorophyll b, carotenoids) were determined according to Lichtenthaler (1987). Quantities of pigments were calculated according to the following equations and the result was evaluated as $\mu \mathrm{g} / \mathrm{ml} / \mathrm{g} \mathrm{FW}$.

Chlorophyll a $(\mathrm{Chl} \mathrm{a})=(11.24 \times$ A661.6) $-(2.04 \times$ A644.8)

Chlorophyll b $(\mathrm{Chl} \mathrm{b})=(20.13 \times \mathrm{A} 644.8)-(4.19 \times \mathrm{A} 661.6)$

Carotenoid $(\mathrm{C} x+\mathrm{c})=[(1000 \times \mathrm{A} 470)-(1.9 \times \mathrm{Chl} \mathrm{a})-(63.14 \times \mathrm{Chl} b)] / 214$

\subsection{Determination of antioxidant enzyme activities}

To reveal the effect of the PGB_invit-plant interaction on the activities of antioxidant enzymes, plant samples were taken in 1st, 3rd and 7th days after inoculation with PGB_invit on QL medium plates. Control group samples were taken in the same days after they subcultured on QL medium plates. $0.2 \mathrm{~g}$ plant samples were homojenized in $1 \mathrm{ml}$ suspension buffer [(50 mM potassium phosphate buffer $(\mathrm{pH} 7.8)$ containing 1 mM ethylenediamine tetraacetic acid (EDTA) and $2 \%$ polyvinyl pyrrolidone (PVP)] with mortar and pestle. Then, homogenates were centrifuged at $13000 \mathrm{~g}$ for 30 minutes at $4^{\circ} \mathrm{C}$ and the supernatants were transferred into new tubes on ice. Total soluble protein content was determined following to Bradford (1976) method. Catalase (CAT), ascorbate peroxidase (APX), glutathione reductase (GR) and guaiacol peroxidase (POX) activities were determined according to the Chance and Maehly (1955), Wang et al. (1991), Sgherri et al. (1994) and Quesada et al. (1990), respectively. All activity experiments were performed as 3 biological and 2 technical replicates.

\subsection{Determination of Proline, Malondialdehyde (MDA) and Hydrogen peroxide $\left(\mathrm{H}_{2} \mathrm{O}_{2}\right)$ contents}


MDA and $\mathrm{H}_{2} \mathrm{O}_{2}$ contents are evaluated following the $1 \mathrm{st}$, 3rd and 7th days of inoculation of plants with PGB_invit on QL medium. Control group samples were also evaluated at the same days after subcultured on QL medium plates. The proline content was determined according to Bates et al. (1973) while MDA and $\mathrm{H}_{2} \mathrm{O}_{2}$ contents of plant samples were determined according to Heath and Packer (1968), and Sergiev et al. (1997), respectively. All the measurements were done with 3 biological and 2 technical replicates.

\subsection{Determination the effect of PGB_invit on rooting and in vivo acclimatization of Fraser's Photinia}

Following optimum in vitro culture without subculturing, microshoots that are inoculated with optimum PGB_invit concentration transferred to semi-solid QL medium with $0.5 \mathrm{mg} / \mathrm{l}$ indole butyric acid (IBA) and without any auxin application for their rooting. The microshoots which are not inoculated with bacterium (control group) were also taken to rooting applications. Microshoots with at least $0.2 \mathrm{~cm}$ roots were accepted as they rooted. The rooting percentages (\%) of microshoots, the number of roots per microshoots and average root lengths $(\mathrm{cm})$ were calculated after they incubated for 4 weeks in a growth room at $25^{\circ} \mathrm{C}$ under a $16 \mathrm{~h}$ photoperiod of $36 \mu \mathrm{mol} \mathrm{m} \mathrm{m}^{-2} \mathrm{~s}^{-1}$ photosynthetic photon flux provided by cool-white fluorescent lamps. Control and PGB_invit inoculated plants which are rooted in vitro conditions were taken from medium and washed under tap water and then they were placed into small pots containing a mixture of sterile soil, peat and perlite for their acclimatization in greenhouse conditions. The first 15 days of transfer, the pots were covered with stretch film for adaptation to low humidity conditions and a hole was gradually opened on the stretch film every day. The plants were irrigated at regular intervals. After 15 days, the stretch films were completely removed and the plantlets continued to grow in greenhouse conditions. At the end of 30 days, the acclimatization percentages (\%) of control and inoculated plants were calculated. At least 30 microshoots were used for rooting and acclimatization experiments and repeated twice.

\subsection{Screening the location of the PGB_invit in plants}

\subsubsection{GFP-Plasmid Transformation}

The bacteria were transformed with a Green Fluorescent Protein (GFP) plasmid (pSEVA227-G) in order to determine the location of PGB_invit. The donor strain Escherichia coli (E. coli) DH5a carrying pSEVA227-G [provided by Victor de Lorenzo Lab, (http://seva.cnb.csic.es/)] to be introduced into PGB_invit strain via conjugation as described in Martínez-García and de Lorenzo (2011). For this aim, the donor strain E. coli DH5a containing pSEVA227-G and E. coli HB101 strain containing the mating helper plasmid pRK600 were grown in LB broth, $50 \mu \mathrm{g} / \mathrm{ml} \mathrm{Kanamycin} \mathrm{(Km),} \mathrm{and} 30 \mu \mathrm{g} / \mathrm{ml} \mathrm{Chloramphenicol}(\mathrm{Cm})$, respectively. Then the cells were washed twice with $10 \mathrm{mM} \mathrm{MgSO}_{4}$ solution and each bacterial suspension was mixed in a 1:1:1 ratio. in $5 \mathrm{ml}$ of $10 \mathrm{mM} \mathrm{MgSO4}$.These mixtures were placed on LB Petri plates in different proportions and allowed to grow at $30^{\circ} \mathrm{C}$. After at least one day, LB Petri plates were washed with $5 \mathrm{ml} 10$ $\mathrm{mM} \mathrm{MgSO}_{4}$ and the cells at appropriate dilutions were spread over the selective medium (MPYE medium containing50 $\mu \mathrm{g} / \mathrm{ml} \mathrm{Km}$ ). After the Petri plates were incubated at $30^{\circ} \mathrm{C}$ for 7 days, GFP-positive colonies were initially selected using the imaging system (Azure Biosystems, C600). Then positive transconjugants were tested by PCR amplification using (5'-GCGGCTGCAGGCATGCAGGAGGAAAAACATATGAGTAAAGG-3'; 5'-GCGGAAGCTTCTATTTGTATAGTTCATCCATGCC$3^{\prime}$ ) primers to confirm the presence of the $\sim 700 \mathrm{bp}$ gfp fragment. The sequence was amplified using Go Taq DNA polymerase (Promega, Madison, WI) and the PCR conditions are: predenaturation at $95^{\circ} \mathrm{C}$ for 2 minutes, 30 cycles with denaturation at $95^{\circ} \mathrm{C}$ for 30 seconds, annealing at $60^{\circ} \mathrm{C}$ for 30 seconds, extension at $72^{\circ} \mathrm{C}$ for 1 minute, and with a final extension at $72^{\circ} \mathrm{C}$ for 10 minutes.

\subsubsection{Inoculation of in vitro Fraser's Photinia microshoots with GFP-labeled PGB_invit}

PGB_invit strain labelled with GFP was grown in MPYE broth (with kanamycin) and density of the bacterial culture was adjusted to 0.6 McFarland with a turbidity-meter. The Fraser's Photinia microshoots those grown in in vitro tissue culture conditions for 60 days were inoculated with the PGB_invit culture in MPYE broth by following steps. $2 \mathrm{ml}$ bacterial culture (0.6 McFarland) was spread over the entire $1 / 2$ MS0 medium (Murashige and Skoog, 1962) of plant tissue culture vessels by Drigalski spatula. After that, shoot and leaf parts of microshoots were cut in a laminar flow cabinet with sterile lancet and placed on the vessels. In addition, to make sure that the inoculation of plant with bacteria, the leaves and shoots were first kept in the bacterial culture for about 10 minutes before they placed on $1 / 2$ MSO mediums. To be used as a control group, some shoot and leaf parts were placed on the plant tissue culture vessels containing only $1 / 2$ MSO medium without bacteria. All the plants were incubated at plant growth chamber for 5 days. $2 \mu$ propidium iodide (PI) was used to stain plant tissues and incubated in dark at room temperature for 20 minutes. Visualition of stained cells were imaged in Zeiss LSM880 Airyscan confocal microscope (Carl Zeiss, Jena, Germany). GFP is stimulated at $488 \mathrm{~nm}$ and the emitted light is gathered at 510-560 nm and becomes visible (Chi et al., 2005). For this purpose, PI was stimulated with wavelength of $488 \mathrm{~nm}$ and a measurement was taken at $565 \mathrm{~nm}$ wavelength. For GFP, it was stimulated with $488 \mathrm{~nm}$ laser and a measurement was taken at $530 \mathrm{~nm}$ wavelength. 10X and 20X objective lenses were used throughout the study.

\subsection{Determination of PGB_invit-Fraser's Photinia Interactions at the Molecular Level}

\subsubsection{RNA isolation}

After 60 days incubation in in vitro conditions, Fraser's Photinia microshoots that were inoculated with active and inactive PGB_invit, and the non-inoculated control group, were taken from culture vessels by sterile forceps and weighed in aseptic conditions. We used $0.3 \mathrm{~g}$ plant material from 3 biological samples for each groups. RNA isolation was performed according to the method described by Spiegel et al. (1996). The concentrations and purity of the isolated RNAs were determined by measuring OD260 \& OD280 using a NanoDrop spectrophotometer (ThermoFisher Scientific), and the integrity of the RNAs was demonstrated by agarose gel electrophoresis. At the end, all samples were stored at $-80^{\circ} \mathrm{C}$ until they were sent for RNA-Seq.

\subsubsection{Sequencing library preparation}

The TruSeq ${ }^{\circledR}$ Stranded Total RNA Sample Preparation Kit (Illumina) was used to prepare a library from total RNAs isolated from inoculated with active (A), inactive (I) PGB_invit and non inoculated control group (C) plants with 3 biological replicates. Paired-end sequencing with read lengths of 150 nt was carried 
out on a HiSeq 4000 instrument (Illumina Inc., San Diego, California, USA).

\subsubsection{Transcriptome sequence assembly and annotation}

The raw data (at least 20 million read pairs for each sample) was processed as follows: first, quality control of the Illumina reads were carried out using FastQC (Andrews, 2010). Adapter regions and sequences with low quality reading were removed from the transcriptome sequences by using Lucy (Chou and Holmes, 2001), Pyrocleaner (Mariette et al., 2011), Figaro (White et al., 2008) and CLC Genomics Workbench (Liu et al., 2020) programs for a more accurate assembly. Overlapping paired-end reads were merged using the Flash program (Magoč and Salzberg, 2011) before assembling reads that were free of adapter and highly repeated sequences. This process facilitated the mapping of differently expressed genes to the reference genome. For reference-guided assembly, apple (Malus $\mathrm{x}$ domestica Borkh.) was selected the taxonomically closest species to Fraser's Photinia within the Rosaceae family for which a high-quality annotated sequence assembly was available. Therefore, the M. domestica cv. 'Golden Delicious' genome GDDH13 v 1.1 (Daccord et al., 2017) pseudomolecules and gene model annotations were downloaded from https://iris.angers.inra.fr/gddh13. Alignment to the reference and transcript quantification was also carried out using the HiSat2-StringTie-Ballgown pipeline (Pertea et al., 2016) with additional file processing using samtools 1.8. In order to account for differences in sequence between $P . x$ fraseri genes and their orthologs in $M$. domestica, HiSat2 was run with the option -score-min L,0,0.5, permitting read alignments of $>90 \%$ sequence identity. Only putative transcripts with at least $5 x$ read coverage were included in subsequent analyses.

\subsubsection{Gene Identification and Ontology}

When assembled transcripts mapped to annotated genes in the M.domestica genome, the functional annotations from apple were transferred. All transcript contigs that did not map to annotated genes were used as queries for BLASTX in the UniProtKB/SwissProt database and NCBI non-redundant (nr) protein database. Contigs with an "E-value" of $<1 \mathrm{e}-5$ and showing more than $80 \%$ homology to known plant proteins, were identified as protein coding gene sequences. These sequences were scanned against the sequences found in the Blast2GO, Ontologizer 2.0 and UniProtKB databases to predict possible functions.

\subsubsection{Determination of differentially expressed transcripts}

The RNA-Seq and expression analysis modules included in the CLC Genomics Workbench program were used to perform the differential expression analysis, with additional analyses in Ballgown. High quality reads from each sample were mapped to the transcriptome assembly created above using CLC Genomics Workbench. For this alignment at least $95 \%$ read coverage was required with no more than two mismatches are allowed. The total number of mapped reads for each transcript was determined and normalized between samples using the FPKM (fragment per kilobase per million mapped reads) method. Transcripts with very low expression (average FPKM $<2$ across all samples) were eliminated. Statistical differences between the control and treatment groups were calculated using a false discovery rate (FDR) adjusted p-value $₫ 0.05$. Statistically significant transcripts with an absolute fold change $>2$ between at least 2 of the test groups were determined as differentially expressed isoforms and genes, which were then are grouped into genes with increased or decreased expression after PGB_invit treatments. All data is shown as log2(FPKM+1) for each sample to check for sample-specific deviations.

\subsubsection{Verification of RNA-Seq data with Real Time Quantitative RT-PCR (qRT-PCR)}

The sequences of RNA-Seq were eximined and candidate genes for qRT-PCR were determined to verify the differences in gene expression seen between trials. Primers designed for the selected genes are presented in Sup. Table 1. Confirmation of differently expressed genes identified by Illumina RNA-Seq with qRTPCR method was performed using cDNAs (complementary DNA) synthesized by Maxima First Strand cDNA Synthesis Kit (Thermo Scientific) from the same RNA extracts. Due to the highest expression levels, 15 genes were selected and these expressions were then compared with RNA-Seq results. qRT-PCR was performed by using StepOnePlus ${ }^{\mathrm{TM}}$ Real-Time PCR System (Applied Biosystems). As reference genes for qRT-PCR, 3 gene whose expression did not differ between trials as a result of RNA-Seq were choosen as candidates.

For qRT-PCR analysis, $0.9 \mu \mathrm{l}(5 \mu \mathrm{M})$ per forward and reverse primer, $1 \mu \mathrm{l}$ cDNA (500 ng), $7 \mu \mathrm{l} 2 \mathrm{x}$ Maxima SYBR Green qPCR Master Mix (Thermo Scientific) and $5.2 \mu \mathrm{l}$ sterile nuclease-free water were added ( $15 \mu \mathrm{l}$ total volume) per each well into 96 well plate for both reference genes and for the genes to be analyzed. For each gene, $1 \mu$ sterile nuclease-free water were added for negative control. The qRT-PCR conditions were as follows: initial denaturation at $95^{\circ} \mathrm{C}$ for 5 minutes and after that 40 cycles at $95^{\circ} \mathrm{C}$ for 15 seconds, $59^{\circ} \mathrm{C}$ for 30 seconds and $72^{\circ} \mathrm{C}$ for 30 seconds for each cycle. The melting curve was adjusted as $95^{\circ} \mathrm{C}$ for 15 seconds, $60^{\circ} \mathrm{C}$ for 1 minute and $95^{\circ} \mathrm{C}$ for 15 seconds. The fold change $2^{\text {-deltaCt }}$ calculated according to the $\mathrm{Ct}$ (cycle threshold) values of each gene were compared with three internal control genes. The data were evaluated with the statistical program.

\subsection{Statistical Analyses}

Analysis of all study results were done by using SPSS 12.0 program. The data were subjected to ANOVA to determine the differences between trials. The differences between the average data were subjected to LSD (least significant difference) multiple comparison test at level of P $\leq 0.05$. Proportional data were statistically evaluated by Chi-square test $\left(\chi^{2}\right)$. Heat-map graph of differently expressed genes among control and PGB_invit (active and inactive) inoculated groups was drawn using Microsoft Excel and GraphPad Prism 8 statistical programme based on the mean values of three replicates.

\section{Results}

\subsection{In vitro proliferation of Fraser's Photinia}

The results of in vitro proliferation of Fraser's Photinia microshoots which obtained after 30 days incubation on QL medium were presented in Table 1. Although, $38 \%$ of all sterilization trials were contaminated, $75-80 \%$ proliferation was obtained from sterile shoot tips. Additionally, multiple shoot formation was also observed. The lengths of microshoots were more than $3.5 \mathrm{~mm}$. The proliferated shoots were subcultured in every 4 weeks for at least 3 months under in vitro conditions and then, they were used for bacterial inoculation experiments. 
Table 1

Proliferation results obtained after 30 days cultivation of Fraser's Photinia microshoots transferred to in vitro conditions ${ }^{\text {a }}$

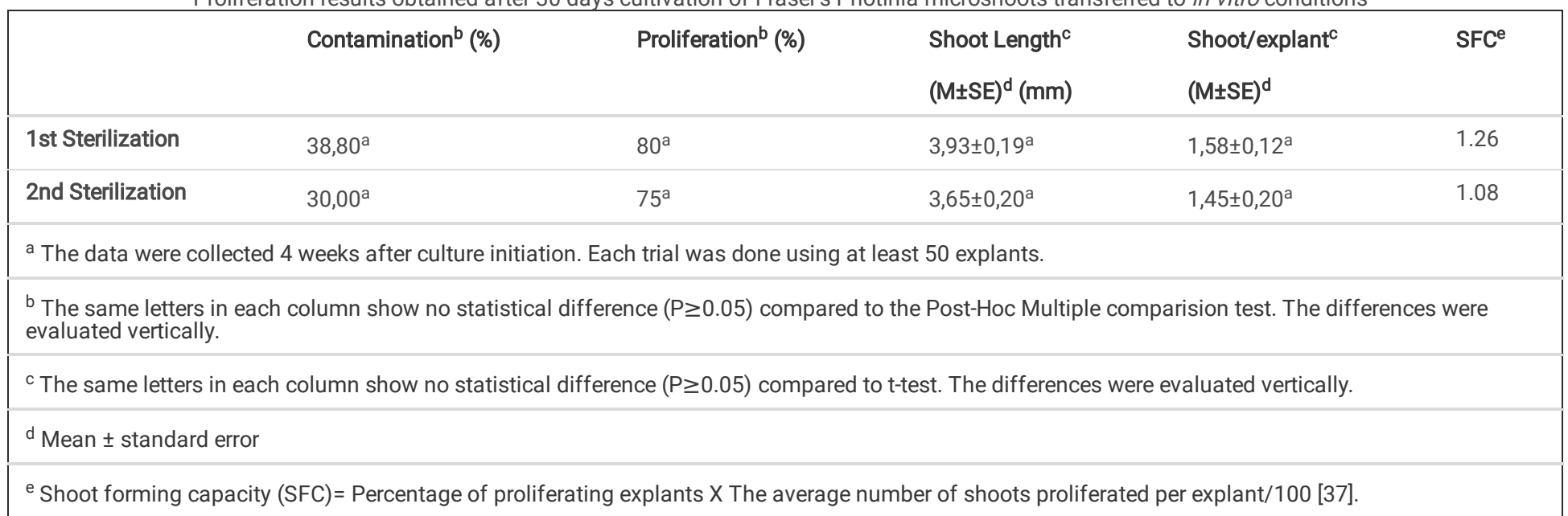

\subsection{Inoculation of Fraser's Photinia microshoots with PGB_invit and the determination of optimum inoculation concentration}

At the end of the incubation for 30 days, it was seen that PSS did not have a negative effect on the proliferation of explants (Table 2). The 30 days incubation period of bacterial inoculation with both inactivated and active PGB_invit did not have a negative effect on the proliferation percentage of the explants, values of average shoot lengths, and the shoot/explant ratio as remarkably increased values were obtained with different incubation bacterium concentration. Elevation of shoot forming capacity [SFC=proliferation percentage. average shoot/explant ratio/100 (Lambardi et al., 1993)] was mostly achieved with inoculation of $10^{2}$ and $10^{4} \mathrm{cfu} / \mathrm{ml}$ of bacterial concentrations (1.80 and 1.82 , respectively).

Table 2

The effect of PGB_invit on proliferation of Fraser's Photinia microshoots after 30, 45 and 60 days inoculation ${ }^{2}$

\begin{tabular}{|c|c|c|c|c|c|c|c|c|c|c|c|}
\hline & 30 Days & & & & 45 Days & & & & 60 Days & & \\
\hline & $\begin{array}{l}\text { Proliferation } \\
(\%)\end{array}$ & $\begin{array}{l}\text { Shoot/ } \\
\text { explant }^{\mathrm{c}} \\
(\mathrm{M} \pm \mathrm{SE})^{\mathrm{d}}\end{array}$ & SFC $^{e}$ & $\begin{array}{l}\text { Shoot } \\
\text { Length }^{c} \\
(\mathrm{M} \pm \mathrm{SE})^{\mathrm{d}} \\
(\mathrm{mm})\end{array}$ & $\begin{array}{l}\text { Proliferation } \\
(\%)\end{array}$ & $\begin{array}{l}\text { Shoot/ } \\
\text { explant }^{c} \\
(M \pm S E)^{d}\end{array}$ & SFC $^{e}$ & $\begin{array}{l}\text { Shoot } \\
\text { Length }^{\mathrm{c}} \\
(\mathrm{M} \pm \mathrm{SE})^{\mathrm{d}} \\
(\mathrm{mm})\end{array}$ & $\begin{array}{l}\text { Proliferation } \\
(\%)\end{array}$ & $\begin{array}{l}\text { Shoot/ } \\
\text { explant }^{c} \\
(M \pm S E)^{d}\end{array}$ & $\mathrm{~s}$ \\
\hline Control & $75.00^{\mathrm{b}}$ & $1.40 \pm 0.13^{b}$ & 1,05 & $3.00 \pm 0.29^{a b}$ & $80.00^{a}$ & $2.81 \pm 0.31^{\mathrm{a}}$ & 2,24 & $3.48 \pm 0.23^{\mathrm{a}}$ & $90.00^{b}$ & $3.18 \pm 0.26^{\mathrm{ab}}$ & 2 \\
\hline PSS & $75.00^{b}$ & $1.45 \pm 0.15^{b}$ & 1,08 & $3.00 \pm 0.30^{\mathrm{ab}}$ & $55.00^{c}$ & $3.36 \pm 0.52^{\mathrm{a}}$ & 1,84 & $3.43 \pm 0.19^{a}$ & $66.66^{\mathrm{e}}$ & $2.80 \pm 0.24^{b}$ & 1, \\
\hline $\begin{array}{l}10^{2} \\
\text { inactive }\end{array}$ & $75.00^{\mathrm{b}}$ & $2.40 \pm 0.29^{\mathrm{a}}$ & 1,80 & $2.75 \pm 0.14^{b}$ & $80.00^{a}$ & $2.37 \pm 0.30^{b}$ & 1,89 & $3.39 \pm 0.17^{a}$ & $93.33^{a}$ & $3.03 \pm 0.29^{\mathrm{ab}}$ & 2 \\
\hline $\begin{array}{l}10^{4} \\
\text { inactive }\end{array}$ & $80.00^{a}$ & $2.43 \pm 0.81^{a}$ & 1,94 & $3.24 \pm 0.16^{a}$ & $75.00^{a b}$ & $3.46 \pm 0.35^{\mathrm{a}}$ & 2,59 & $3.20 \pm 0.13^{\mathrm{ab}}$ & $90.00^{\mathrm{b}}$ & $3.11 \pm 0.28^{\mathrm{ab}}$ & 2 , \\
\hline $\begin{array}{l}10^{6} \\
\text { inactive }\end{array}$ & $80.00^{a}$ & $2.12 \pm 0.23^{a}$ & 1,69 & $3.02 \pm 0.16^{a b}$ & $75.00^{a b}$ & $2.20 \pm 0.26^{b}$ & 1,65 & $2.96 \pm 0.19^{b}$ & $93.33^{\mathrm{a}}$ & $3.28 \pm 0.22^{\mathrm{ab}}$ & 3 \\
\hline $\begin{array}{l}10^{2} \\
\text { active }\end{array}$ & $80.00^{a}$ & $2.12 \pm 0.30^{\mathrm{a}}$ & 1,69 & $2.97 \pm 0.13^{\mathrm{ab}}$ & $80.00^{a}$ & $2.94 \pm 0.30^{\mathrm{a}}$ & 2,35 & $2.97 \pm 0.10^{b}$ & $76.66^{d}$ & $2.73 \pm 0.19^{b}$ & 2 \\
\hline $\begin{array}{l}10^{4} \\
\text { active }\end{array}$ & $75.00^{\mathrm{b}}$ & $2.20 \pm 0.20^{\mathrm{a}}$ & 1,65 & $3.18 \pm 0.21^{\mathrm{ab}}$ & $75.00^{a b}$ & $2.93 \pm 0.45^{a}$ & 2,19 & $3.59 \pm 0.17^{a}$ & $80.00^{c}$ & $3.60 \pm 0.30^{\mathrm{a}}$ & 2 \\
\hline $\begin{array}{l}10^{6} \\
\text { active }\end{array}$ & $60.00^{c}$ & $2.08 \pm 0.33^{a}$ & 1,24 & $3.08 \pm 0.22^{\mathrm{ab}}$ & $70.00^{b}$ & $2.78 \pm 0.47^{a b}$ & 1,94 & $3.20 \pm 0.16^{\mathrm{ab}}$ & $93.33^{\mathrm{a}}$ & $3.18 \pm 0.21^{\mathrm{ab}}$ & 2 \\
\hline
\end{tabular}

${ }^{a}$ Each trial was done using at least 30 explants

b The different letters in each column show statistically significant differences $(P \leq 0.05)$ compared to the Post-Hoc Multiple comparision test. The difference: vertically.

${ }^{\mathrm{c}}$ The different letters in each column show statistically significant differences $(P \leq 0.05)$ compared to LSD test. The differences were evaluated vertically.

${ }^{\mathrm{d}}$ Mean \pm standard error

e Shoot forming capacity $(S F C)=$ Percentage of proliferating explants $X$ The average number of shoots proliferated per explant/100 [37] 
The same positive effect was observed for shoot/explant ratio with bacterial inoculation period for 45 days (Table 2) and 60 days (Table 2). Although the highest shoot/explant ratio was found for the explants inoculated with active bacteria at a concentration of $10^{4}$ for 60 days, the highest SFC ratio was found at $10^{6}(2.96)$ among the active bacteria concentrations tested. The longest average shoot length (3.68 mm) was also measured at this concentration. For this reason, $10^{6}$ was chosen as the optimum PGB_invit concentration that stimulates plant proliferation for bacterial trials that should be done with the active form. Same incubation concentration was also optimum for induction of proliferation of Fraser's Photinia microshoots after 60 days in inactive form (Table 2).

\subsection{Determination the effect of PGB_invit on photosynthetic pigments}

According to the results after 30 days incubation, there was no statistical difference in the amount of chlorophyll a, chlorophyll b and carotenoid of the microshoots inoculated with PGB_invit compared to the control group (Table 3).

Table 3

The effect of 30 days inoculation with $10^{6} \mathrm{cfu} / \mathrm{ml}$ active PGB_invit on the concentration of photosynthetic pigments ${ }^{\mathrm{a}}$

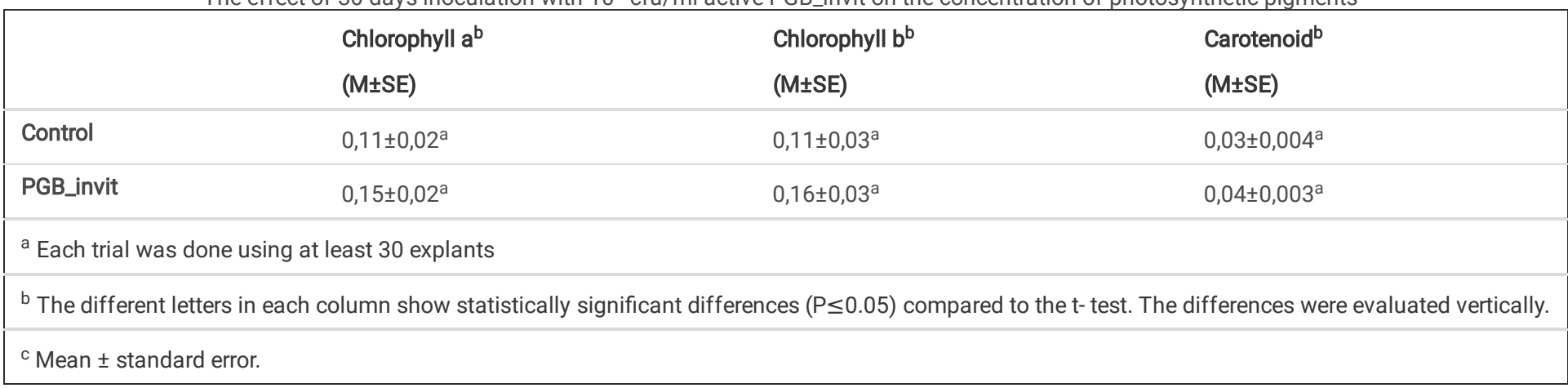

\subsection{Determination of antioxidant enzyme activity}

Although no difference was obtained in catalase activity of the active PGB_invit inoculated explants on 1st and 7th days of post-inoculation, it was statistically higher in 3rd day of post-inoculation in comparision to the control plants (Figure 1). In contrast, APX activity of microshoots of Fraser's Photinia inoculated with $10^{6} \mathrm{cfu} / \mathrm{ml}$ active PGB_invit was decreased in only the first day compared to the control plants and it found statistically significant. In the other incubation days (3rd and 7th ), there was no difference between the plant groups (Figure 1).

\subsection{Determination of Proline Amount}

On the first and third day of post-inoculation, proline amount was statistically higher in active PGB_invit inoculated samples than the control group. The plants inoculated with PGB_invit have no significant changes in amount of proline on the the 7th day while only 3rd and 7th days in the control group has been a slight increase in the control group (Table 4).

Table 4

Proline, MDA and $\mathrm{H}_{2} \mathrm{O}_{2}$ level differences of PGB_invit inoculated and control groups in the 1st, 3rd and 7th day of inoculation ${ }^{\mathrm{a}}$

\begin{tabular}{|c|c|c|c|c|c|c|}
\hline & \multicolumn{2}{|c|}{ 1st Day $(M \pm S E)^{c}$} & \multicolumn{2}{|c|}{ 3rd Day $(M \pm S E)^{c}$} & \multicolumn{2}{|c|}{ 7th Day $(M \pm S E)^{c}$} \\
\hline & Control & PGB_invit & Control & PGB_invit & Control & PGB_invit \\
\hline Proline & $103 \pm 14,0^{\mathrm{a}}$ & $140,5 \pm 17,5^{\mathrm{b}}$ & $130 \pm 8,0^{\mathrm{a}}$ & $150 \pm 2,0^{b}$ & $142 \pm 8,0^{\mathrm{a}}$ & $152 \pm 2,0^{a}$ \\
\hline MDA & $116,6 \pm 16,5^{a}$ & $147 \pm 9,5^{a}$ & $133,1 \pm 15,7^{a}$ & $155,8 \pm 14,4^{a}$ & $202,3 \pm 37,0^{\mathrm{a}}$ & $176,5 \pm 25,0^{a}$ \\
\hline $\mathrm{H}_{2} \mathrm{O}_{2}$ & $122,2 \pm 8,4^{\mathrm{a}}$ & $105,7 \pm 33,6^{a}$ & $199,4 \pm 1,5^{b}$ & $172,8 \pm 1,0^{\mathrm{a}}$ & $172 \pm 13,1^{\mathrm{a}}$ & $186,2 \pm 16,3^{a}$ \\
\hline \multicolumn{7}{|c|}{${ }^{a}$ Each trial was done using at least 0.2 grams of explants } \\
\hline \multicolumn{7}{|c|}{$\mathrm{b}$ The different letters in each row show statistically significant differences $(P \leq 0.05)$ compared to the t- test. The differences were evaluated horizontally. } \\
\hline
\end{tabular}

\subsection{Determination of Malondialdehyde (MDA) ve Hydrogen Peroxide $\left(\mathrm{H}_{2} \mathrm{O}_{2}\right)$ Quantities}

There was no statistically significant difference in the amount of MDA between the control and PGB_invit inoculated plants on days 1, 3 and 7 (Table 4). However, the amount of $\mathrm{H}_{2} \mathrm{O}_{2}$ increased on the 3rd day in control plants while it decreased in plants inoculated with PGB_invit (Table 4). There was no significant difference between the plant groups on the other days (1st and 7th ).

\subsection{Determination the effect of PGB_invit on rooting and in vivo acclimazitation of Fraser's Photinia}


In IBA-free mediums, no rooting was observed in microshoots proliferated from bacterium inoculated plants and non-inoculated control plants. With the addition of $0.5 \mathrm{mg} / \mathrm{I}$ IBA to the medium, both control and bacteria-inoculated microshoots were rooted (55\% and $60 \%$ respectively), (Table 5 ). Similar to the percentage of rooting, no statistical difference was recorded in the number of roots per microshoots and the average root length for both groups planted on $0.5 \mathrm{mg} / \mathrm{I}$ IBA containing medium (Figure 2). In addition, the percentages of survival after in vivo acclimatization of PGB_invit inoculated and control group plants was similar ( $80 \%$ and $75 \%$, respectively) at the end of 30 days in greenhouse conditions.

Table 5

The effect of PGB_invit on rooting of Fraser's Photinia ${ }^{a}$

\begin{tabular}{|c|c|c|c|}
\hline Parameters & Rooting $^{\mathrm{b}}(\%)$ & Root/microshoot ${ }^{c}(M \pm S E)^{d}$ & $\begin{array}{l}\text { Root length } \\
(\mathrm{M} \pm \mathrm{SE})^{\mathrm{d}}(\mathrm{mm})\end{array}$ \\
\hline \multicolumn{4}{|l|}{ IBA (0 mg/l) } \\
\hline Control & $0^{b}$ & $0^{\mathrm{b}}$ & $0^{\mathrm{b}}$ \\
\hline $10^{6}$ active $P G B \_i n v i t$ & $0^{b}$ & $0^{\mathrm{b}}$ & $0^{\mathrm{b}}$ \\
\hline \multicolumn{4}{|l|}{ IBA (0.5 mg/l) } \\
\hline Control & $55.0^{\mathrm{a}}$ & $1.7 \pm 0.2^{\mathrm{a}}$ & $1.9 \pm 0.2^{a}$ \\
\hline $10^{6}$ active $P G B \_i n v i t$ & $60.0^{\mathrm{a}}$ & $1.5 \pm 0.3^{a}$ & $2.0 \pm 0.4^{\mathrm{a}}$ \\
\hline \multicolumn{4}{|c|}{ a The data were collected 4 weeks after culture initiation. Each trial was done using at least 30 microshoots.. } \\
\hline \multicolumn{4}{|c|}{$\begin{array}{l}\text { b The different letters in each column show statistically significant differences }(P \leq 0.05) \text { compared to the Post-Hoc Multiple comparision test. The } \\
\text { differences were evaluated vertically. }\end{array}$} \\
\hline \multicolumn{4}{|c|}{${ }^{c}$ The different letters in each column show statistically significant differences $(P \leq 0.05)$ compared to LSD test. The differences were evaluated vertical } \\
\hline
\end{tabular}

\subsection{Monitoring localization of GFP-labelled bacterium in plant cells}

After conjugation, GFP positive candidate colonies in Petri dishes were selected using the imaging system (Azure Biosystems, C600) and then positive transconjugants were also confirmed with the presence of the gfp gene by PCR amplification. In addition, PCR amplification was also carried out with aux primers to verify the presence of endophytic bacteria-specific auxin gene (aux) in the same colonies (Figure $3 \mathrm{~A}$ ).

Epiphytic and endophytic bacterial colonization was observed in the cross sections of Fraser's Photinia microshoots and it was visualized that the bacterium is endophytic (Figure 3B, 3C).

\subsection{Determination of plant-PGB_invit interaction with molecular analyzes}

Total RNA was isolated from the emerging microshoots of Fraser's Photinia explants that were inoculated with $10^{6} \mathrm{cfu} / \mathrm{ml}$ active or inactive PGB_invit, along with non-inoculated controls, after 60 days cultivation under in vitro conditions. RNA-seq analysis was carried out, and the total amount of raw data and the results of quality filtering are presented in Sup. Table 2. Unpaired reads, and paired reads with poor quality, were eliminated and not used in later stages. As can be seen in Sup. Table 2, for all samples $>95 \%$ of reads were of good quality and sufficient to create the data of next analysis.

Sup. Table 3 and 4 shows the number of reads that were mapped to the reference genome/transcriptome for each of the samples in the experiment. As the reference genome (apple) was a different species, most reads did not map with very high percentage identity; as a result, only $35-41.9 \%$ of the total reads from Fraser's Photinia were mapped to the reference genome (Sup. Table 3) using CLC Genomics with default parameters. However, using HiSat2 with an empirically determined relaxed mapping quality score (corresponding to $\geq 90 \%$ sequence identity) $69.42-80.17 \%$ of read pairs were successfully mapped HiSat2 (Sup. Table 4). The similarities and differences in the distribution of gene expression between the two trials can be clearly seen when these figures are examined by evaluating these gene expression differences. According to gene expression levels (FPKM) from the CLC Genomics mapping results (Sup. Table 5), it was found that 35 of the 100 most abundant genes were differentially expressed amoung groups. 26 of these genes were upregulated and 5 of them were downregulated in active and inactive PGB_invit inoculated groups when compared to the control. From these 35 genes, 4 of them have expression levels which are varies (up or downregulated) among active and inactive PGB_invit inoculated groups when they compared to the control group. From all these differently expressed genes, XP_028953023, XP_008344383, XP_028943716, XP_008351175 and XP_028948163 genes were chosen to confirm expression differences by qRT-PCR.

Following the mapping according to HiSat2 and statistical analyses performed with Ballgown software, among the groups the 10 genes with the highest expression differences with $>2$-fold change in FPKM levels (Sup. Table 6) were selected to confirm gene expression by qRT-PCR. (Expression level changes of these genes are shown in Sup. Table 7).

BLAST results of these selected a total of 15 genes are also presented in Sup. Table 8. In addition, heat map of gene expression level changes of these genes presented in Figure 4. According to this results, one variant of the gene which is numbered with XP_008352422.1 (predicted "MID1-Complementing Activity 1") was upregulated and the other variant is downregulated in active PGB_invit inoculated group. 3 variants of XP_009355189.1 (Predicted "Two pore potassium 
channel-1 like") are upregulated and 2 variants are downregulated in inactive PGB_invit inoculated group. For XP_008385478.1 (Aspartic proteinase-like protein 2), one variant is upregulated and the other variant is downregulated in inactive group. One variant of XP_009359787.1 (uncharacterized ABC transporter-like) is upregulated both active and inactive PGB_invit inoculated groups and the other variant is have nearly the same expression levels in all groups. The gene numbered with XP_008375951.1 (Predicted "apoptosis inducing factor homolog B-like") is upregulated both active and inactive PGB_invit inoculated groups but its expression level is higher in inactive group. KAB2620082.1 (RNA-dependent RNA polymerase I) have 6 variants and 3 of them is upregulated, 3 of them is downregulated in active and inactive PGB_invit inoculated groups compared to the control. 2 variants of XP_028948963.1 (Predicted "E3 ubiquitin-protein ligase RHA1B-like") is upregulated and 1 variant is downregulated in active and inactive PGB_invit inoculated groups. PWZ54828.1 (Ubiquitin conjugating enzyme E2) have 2 variants and intrestingly one of them seen upregulated in all groups but expression levels are I, A, C, respectively, from highest to lowest. XP_028953023 (Methionine aminopeptidase 2B-like) is upregulated in active and inactive PGB_invit inoculated groups but its expression level is higher in the inactive group than active group. XP_008344383.2 (plasmodesmata-located protein 8) is upregulated in active PGB_invit inoculated group. XP_028943716 (UDP-glycosyltransferase 92A1-like isoform X2) seen upregulated in all groups but their expression levels are A, I, C, respectively, from highest to lowest. XP_008351175.2 (probable protein phosphatase 2C 34) is upregulated in active and inactive PGB_invit inoculated groups where it is downregulated in control group. And finally gene XP_028948163.1 (4-coumarate-CoA ligase-like 9) is upregulated in active and inactive PGB_invit inoculated groups but it has a higher expression level in inactive group than active group.

\subsubsection{Verification of RNA-seq data by qRT-PCR}

Of the selected 15 genes, gene bank ID XP_008352422.1 (predicted “MID1-complementing activity 1"), PWZ54828.1 (Ubiquitin conjugating enzyme E2), XP_028948963.1 (predicted “E3 ubiquitin-protein ligase RHA1B-like"), XP_008339965.2 (uncharacterized protein), XP_028948163.1 (4-coumarate-CoA ligaselike 9) XP_028953023 (methionine aminopeptidase 2B-like) expression levels were confirmed by qRT-PCR (Figure 5). The expression levels of XP_008352422.1, PWZ54828.1, XP_028948963.1, XP_008339965.2 genes decreased in plant samples inoculated with active and inactive bacteria compared to the control in accordance with RNA-seq results. Expressions levels of XP_028953023 and XP_028948163.1 genes increased in comparison to control in samples inoculated with active and inactive bacteria. However, XP_008375951.1, XP_009359787.1, XP_009338507.1, XP_008385478.1, XP_009355189.1, KAB2620082.1, XP_008351175.2, XP_008344383.2 and XP_028943716, which had expression differences in the samples inoculated with active bacteria compared to the control could not be verified with qRT-PCR because statistically no difference could be detected between trials (Sup. Figure 3 ).

\section{Discussion}

PGB_invit is reported previously to have nitrogen fixing ability and also GA3 and IAA producing capability (Gül Şeker et al., 2017). Hence, in our previous study (Batool et al., 2019), the inoculation of the Arabidopsis thaliana with the same PGB_invit bacteria, also showed that the PGB_invit culture has a positive effect on the proliferation of microshoots and multiple shoot formation. In accordance, these beneficial influences of PGB_invit on Fraser's Photinia shoot proliferation were also evidenced in our study. Among the different concentrations of PGB_invit inoculated into Fraser's Photinia shoot tips for various in vitro cultivation periods, $10^{6} \mathrm{cfu} / \mathrm{ml}$ found to be the most efficient one in active and inactive form. Moreover, the positive effects were observed especially in long incubation period (60 days) probably due to the slow generation time of PGB_invit. Besides, PGB_invit inoculation did not have any detrimental influence on rooting and in vivo acclimatization of Fraser's Photinia microsoots. Moreover, our hypothesis, that PGB_invit can be an endophytic bacterium (Şah et al., 2019) is proven with the results presented in this study. Confocal microscopy photographs of cross sections of Fraser's Photinia with the colonization of epiphytic and endophytic GFP-labeled PGB_invit shows clearly this in Figures 3B and 3C. The aim of this study was to elucidate the molecular mechanisms of Fraser's Photinia and PGB_invit relationship.

Plants that encountered with biotic stress possess oxidative stress that occurs when there is a serious imbalance of production of reactive oxygen species (ROS) and antioxidant defense system (Anjum et al., 2012). The presence of high concentration of ROS in cells causes oxidative damage to photosynthetic functions and vital bio-molecules, and disrupt cellular metabolism. Therefore, photosynthetic pigments and MDA levels were determined in this study to reveal out if PGB_invit incubation leads to a serious oxidative stress in Fraser's photinia in vitro cultures. Our results confirmed that there is no either any negative influence of this bacterium on photosynthetic pigments amount or distruption of cellular membranes due to ROS formation.

Although no change in MDA levels obtained in this study, we still try to understand how Fraser's Photinia respond to possible oxidative stress generated by PGB_invit in antioxidant level as plants have mechanisms to reduce ROS caused by biotic stress with antioxidant enzymes such as CAT, superoxide dismutase (SOD), GR, APX, and non-enzymatic antioxidants like ascorbic acid, proline and glutathione (Janků et al., 2019). A decrease in $\mathrm{H}_{2} \mathrm{O}_{2}$ amount due to the increase in the activity of catalase enzyme on the 3rd day after inoculation of Fraser's Photinia shoot tips was determined with $10^{6}$ cfu/ml active PGB_invit under in vitro conditions. All enzyme activity results showed that PGB_invit did not induce Fraser's Photinia's antioxidant mechanisms except catalase. Moreover, proline was also increased at the 1st day of inoculation, probably due to initial interaction. Overall biochemical results demostrated that this bacterium does not cause major oxidative stress on its host and hence does not evoked alot antioxidant defence system.

As a result of our molecular analyses, we identified 45 genes in total that were differently expressed in active and inactive PGB_invit inoculated groups when compared to control group. From these 45 genes, 26 of them were upregulated, while 17 were downregulated in active and inactive PGB_invit inoculated groups. In addition, 6 of them had expression levels which varied (up or downregulated) between active and inactive PGB_invit inoculated groups. And finally, three of these 45 genes had expression level changes which varied according to different isoforms of the same gene transcript.

Among all the differently expressed genes, 15 of them were selected for qRT-PCR analysis and six of them were verified (Figure 5). Three of these genes (XP_028948963.1, XP_008339965.2, PWZ54828.1) expression were found to vary according to the isoform. This refers to the different use of transcript isoforms of the same gene depending on the conditions. However, since there is no database for the Fraser's Photinia yet, studies based on Arabidopsis, maize and rice plants in the literature were used to evaluate the function of the last three genes (Sup. Table 7), whose gene expression varies according to isoform. In 
the literature, RHA1B-like E3 ubiquitin-protein ligase gene is an enzyme investigated in Arabidopsis and rice and it has been reported that gene expression increases especially in biotic and abiotic stress conditions (Mazzucotelli et al., 2006). E3 ligases play an important role in post-translational modification as they define the substrate specificity of the ubiquitination complex (Diaz-Granados et al., 2020). Naturally, an increase in the expression of genes encoding this enzyme (XP_028948963.1) is expected in plant samples inoculated with active PGB_invit (Sup. Figure 2). Identified with the PWZ54828.1 genebank ID number Ubiquitin conjugating enzyme E2 (Zea mays) is involved in the protein ubiquitination mechanism; operates in tolerance to abiotic and biotic stress (Kim et al., 2005). According to studies in wild rice, the expression of the $O g U B C 1$ gene encoding E2 was increased when it was treated with injury and microbeassociated molecular motifs (MAMPs) and salicylic acid or exposed to UV-B radiation (Liu et al., 2020). Ectopic expression of the OgUBC1 gene in Arabidopsis triggered the accumulation of anthocyanins in the leaves of the genes associated with defense and stress. In addition, these plants expressing the gene in question are resistant to UV-B related cell damage and Botrytis cinerea infection. In this study, while the gene in question has to increase its expression due to the biotic stress factors applied under in vitro conditions, its expression has decreased in the samples inoculated with both active and inactive PGB_invit compared to the control samples. This situation shows that the inoculation with PGB_invit does not cause stress on the Fraser's Photinia once again.

In addition, according to BLAST results, we performed qRT-PCR analysis to verify gene expression level changes and in the result of this RNA-Seq and qRT-PCR had been performed on Fraser's Photinia for the first time in our study.

According to the qRT-PCR results, the genes named with XP_008352422.1, XP_028948163.1 and XP_028953023 were found out that they are coding mid1complementary activity (MCA) protein, 4-coumarate-CoA ligase and methionine amino protease (MetAP2), respectively and their expression level changes were verified with qRT-PCR. The mid1-complementary activity (MCA) protein family are found in plasma membrane and shown to function as $\mathrm{Ca}^{2+}{ }^{2}$-permeable mechanosensitive channels. They participate in $\mathrm{Ca}^{2+}$ uptake at the roots. MCA channels appear to have common functions in plants, based on studies on Oryza sativa OsMCA1, Nicotiana tabacum NtMCA1, NtMCA2, Zea mays CNR13 (Nishii et al., 2021). Experiments with various cell types have shown that increasing the expression of the MCA gene increases $\mathrm{Ca}^{+2}$ uptake under normal and membrane-disrupting conditions (Nakano et al., 2011). Furthermore, the reduction of MCA in Fraser's Photinia plants inoculated with active PGB_invit shows that the biotic agent does not increase Ca ${ }^{+2}$ uptake into the cell as it does not cause stress in the plant.

Expression of 4-coumarate-CoA ligase is optimized at developmental stages and in response to biotic and abiotic stresses (Lavhale et al., 2018). The 4coumarat-CoA ligase-like 9 gene plays a role in the conversion of a-linolenic acid to jasmonic acid (JA). Therefore, this protein is seen as an enzyme involved in the activation of JA biosynthesis. It is known that jasmonic acid is one of the two main plant growth regulators that play a role in regulating the plant defense system against biotic and abiotic stresses while the complex interactions of jasmonic acid with salicylic acid, other plant growth regulators such as ABA and cytokinins also play a role (Robert-Seilaniantz et al., 2011; Erb et al., 2012). In this respect, the increase of gene expression compared to the control of the gene of interest in plant samples inoculated with active and inactive PGB_invit shows that this bacterium activates JA biosynthesis in the plant.

Methionine amino protease (MetAP2) whose gene expression is increased in plants inoculated with active and inactive PGB_invit compared to control, is the most important component of the N-terminal methionine extraction (NME) pathway that removes the first methionine of proteins and catalyzes the basic posttranslational modification. N-terminal methionine extraction is the main universal process, protected from eubacteria to higher eukaryotes. NME is regulated by stress (Giglione et al., 2004) and it is well known that it is necessary for proper plant growth in Arabidopsis (Ross et al., 2005). Although there is not much publication about the effects of MAP in response to stress in plants, it has been reported that a new MAP protein (HvMAP) in barley has increased gene expression in samples treated with low temperature (Jeong et al., 2011). In addition, transgenic Arabidopsis lines expressing this gene in large amounts have been observed to have a relatively strong freezing tolerance compared to wild types. These results suggest that, HVMAP functions in freezing tolerance by facilitating protein maturation in the conditioning process. In this study, an increase in the expression of this gene in the plants inoculated with active and inactive PGB_invit may be associated with biotic agent inducing plant growth by causing a large amount of protein to mature.

\section{Conclusion}

In summary, physiological, biochemical and molecular effects of the PGB_invit are evaluated together on the Fraser's Photinia plant under in vitro conditions and optimum PGB_invit concentration that increases in vitro proliferation of Fraser's Photinia is determined as $10^{6} \mathrm{cfu} / \mathrm{ml}$. PGB_invit inoculation relatively increased the amount of chlorophyll and did not cause a remarkable oxidative stress. It also has been confirmed that the localization of the PGB_invit in question is endophytic. According to RNA-seq results of Fraser's Photinia plants inoculated with active bacteria, the induction or reduction of expression of several genes [gene bank ID XP_008352422.1 (predicted "MID1-complement activity 1"), PWZ54828.1 (ubiqutin conjugated enzyme E2), XP_028948963.1 (predicted "E3 ubiquitin-protein ligase" RHA1B-like"), XP_008339965.2 (uncharacterized protein), XP_028948163 (4-coumarat-CoA ligase-like 9), XP_028953023 (methionine aminopeptidase 2B-like) were verified by qRT-PCR. It has been identified three internal control genes to be used for plantPGB_invit interaction [XP_008338169.1 (ubc12-like NEDD-conjugating enzyme, VVA10186.1 (20 kDa predicted chaperone), XP_017186573.2 (50S ribosomal protein L28, chloroplastic like) for the first time in Fraser's Photinia.

Our results in this study together with our previous studies have been demonstrated that PGB_invit has a positive impact on plants growth and development with several mechanisms. Besides its shown that PGB_invit is not act as a stress factor, as it does not cause a severe oxidative stress and thus can be used as a biofertilizer.

\section{Declarations}

\section{DECLARATION OF COMPETING INTEREST}


The authors declare that they have no conflict of interest. This article does not contain any studies with human participants or animals performed by any author. Sponsors did not have any role in study design; the collection, analysis and interpretation of data; in the writing of the report; or in the decision to submit the article for publication.

\section{ACKNOWLEDGEMENTS}

We dedicated this study to dear Muhammed Hamit Ekinci who we lost with a sudden heart attack in an early age.

\section{Funding}

This study was supported by TÜBITAK (THE SCIENTIFIC AND TECHNOLOGICAL RESEARCH COUNCIL OF TURKEY) with grant of $117 R 002$ numbered research project.

\section{Competing Interests}

All Authors declare they have no financial interests.

\section{Author Contributions}

NT, MK, HE, conducted the research, YÖÇ, ÖA, MGŞ, CK planned all the experiments, SJL carried out bioinformatic analysis, All of the authors contributed to the writing of the MS.

\section{References}

1. Adesemoye A, Torbert H, Kloepper J (2009) Plant growth promoting rhizobacteria allow reduced application rates of chemical fertilizers. Microb Ecol 58(4):921-929. doi: 10.1007/s00248-009-9531-y. Epub 2009 May 23. PMID: 19466478

2. Andrews S (2010) FastQC: a quality control tool for high throughput sequence data. Available online at: http://www.bioinformatics.babraham.ac.uk/projects/fastqc

3. Anjum NA, Umar S, Ahmad A (2012) Oxidative Stress in Plants: Causes, Consequences and Tolerance, 1st Edition, IK International Publishing House Pvt. Ltd., New Delhi, India, 2012. ISBN: 9789381141021

4. Babalola $O 0$ (2010) Beneficial bacteria of agricultural importance. Biotechnol Letters 32:1559-1570. https://doi.org/10.1007/s10529-010-0347-0

5. Bates LS, Waldren RP, Teare ID (1973) Rapid determination of free proline for water-stress studies. Plant Soil 39:205-207. https://doi.org/10.1007/BF00018060

6. Batool M, Akkaya Ö, Gül Şeker M, Özden Çiftçi Y (2019) Biohardening of Arabidopsis thaliana Seeds and Seedlings with Fraser Photinia Associated Bacterium (PGB_invit) in in vitro Conditions. Notulae Botanicae Horti Agrobotanici Cluj-Napoca 47:954-961. https://doi.org/10.15835/nbha47311488

7. Bradford MM (1976) A rapid and sensitive method for the quantification of microgram quantities of protein utilizing the principal of protein-dye binding. Anal Biochem 72:248-254. DOI: 10.1006/abio.1976.9999

8. Chance B, Maehly AC (1955) The Assay of catalases and peroxidases. Methods in Enzymology 2:764-777. https://doi.org/10.1016/S00766879(55)02300-8

9. Chauhan A, Saini R, Sharma JC (2022) Plant growth promoting rhizobacteria and their biological properties for soil enrichment and growth promotion. Journal of Plant Nutrition 45:273-299 Published online: 06 Agust 2021. https://doi.org/10.1080/01904167.2021.1952221

10. Chen Q, Liu S (2019) Identification and characterization of the phosphate-solubilizing bacterium Pantoea sp. S32 in Reclamation Soil in Shanxi, China. Frontiers in Microbiology 10:2171. https://doi.org/10.3389/fmicb.2019.02171

11. Chi F, Shen S-H, Cheng H-P, Jing Y-X, Yanni YG, Dazzo FB (2005) Ascending Migration of Endophytic Rhizobia, from Roots to Leaves, inside Rice Plants and Assessment of Benefits to Rice Growth Physiology. Appl Environ Microbiol 71(11):7271-7278. doi: 10.1128/AEM.71.11.7271-7278.2005

12. Chou HH, Holmes MH (2001) DNA sequence quality trimming and vector removal. Bioinformatics 17(12):1093-1104. doi: 10.1093/bioinformatics/17.12.1093

13. Daccord N, Celton JM, Linsmith G et al (2017) High-quality de novo assembly of the apple genome and methylome dynamics of early fruit development. Nat Genet 49:1099-1106. https://doi.org/10.1038/ng.3886

14. Davidson E, Prince RC, Haith CE, Daldal F (1989) The cytochrome bc1 complex of Rhodobacter sphaeroides can restore cytochrome c2-independent photosynthetic growth to a Rhodobacter capsulatus mutant lacking cytochrome bc1. J Bacteriol 171(11):6059-6068. doi: 10.1128/jb.171.11.60596068.1989

15. Diaz-Granados A, Sterken MG, Overmars H, Ariaans R, Holterman M, Pokhare SS, Yuan Y, Pomp R, Finkers-Tomczak A, Roosien J, Slootweg E, Elashry A, Grundler FMW, Xiao F, Goverse A, Smant G (2020) The effector GpRbp-1 of Globodera pallida targets a nuclear HECT E3 ubiquitin ligase to modulate gene expression in the host. Mol Plant Pathol 21(1):66-82. doi: 10.1111/mpp.12880

16. Erb M, Meldau S, Howe GA (2012) Role of phytohormones in insect-specific plant reactions. Trends Plant Sci 17(5):250-259. doi: 10.1016/j.tplants.2012.01.003

17. Giglione C, Boularot A, Meinnel T (2004) Protein N-terminal methionine excision. Cell Mol Life Sci 61(12):1455-1474. doi: 10.1007/s00018-004-3466-8

18. Gül Şeker M, Şah I, Kırdök E, Ekinci H, Özden Çiftçi Y, Akkaya Ö (2017) A hidden plant growth promoting bacterium isolated from in vitro cultures of fraser photinia. Int J Agric Biol 19:1511-1519. doi: 10.17957/IJAB/15.0455

Page $11 / 17$ 
19. Heath RL, Packer L (1968) Photoperoxidation in isolated chloroplasts. I. Kinetics and stoichiometry of fatty acid peroxidation. Arch Biochem Biophys 125(1):189-198. doi: 10.1016/0003-9861(68)90654-1

20. Hernández-Soberano C, Ruíz-Herrera LF, Valencia-Cantero E (2020) Endophytic bacteria Arthrobacter agilis UMCV2 and Bacillus methylotrophicus M4-96 stimulate achene germination, in vitro growth, and greenhouse yield of strawberry (Fragaria $\times$ ananassa). Scientia Horticulturae 261:109005. https://doi.org/10.1016/j.scienta.2019.109005

21. Janků M, Luhová L, Petřivalský M (2019) On the Origin and Fate of Reactive Oxygen Species in Plant Cell Compartments. Antioxidants 8(4):105. doi:10.3390/antiox8040105

22. Jeong HJ, Shin JS, Ok SH (2011) Barley DNA-binding methionine aminopeptidase, which changes the localization from the nucleus to the cytoplasm by low temperature, is involved in freezing tolerance. Plant Sci 180(1):53-60. doi: 10.1016/j.plantsci.2010.09.004

23. Kargapolova KY, Burygin GL, Tkachenko OV, Evseeva NV, Pukhalskiy YV, Belimov AA (2020) Effectiveness of inoculation of in vitro-grown potato microplants with rhizosphere bacteria of the genus Azospirillum. Plant Cell, Tissue and Organ Culture (РCTOC). 141:351-359. https://doi.org/10.1007/s11240-020-01791-9

24. Kelly S, Mun T, Stougaard J, Ben C, Andersen SU (2018) Distinct Lotus japonicus Transcriptomic Responses to a Spectrum of Bacteria Ranging From Symbiotic to Pathogenic. Front. Plant Sci 9:1218. doi: 10.3389/fpls.2018.01218

25. Khan MS, Gao J, Chen X, Zhang M, Yang F, Du Y et al (2020) Isolation and Characterization of Plant Growth-Promoting Endophytic Bacteria Paenibacillus polymyxa SK1 from Lilium lancifolium. BioMedResearchInternational, vol. 2020, Article ID 8650957, 17 pages

26. https://doi.org/10.1155/2020/8650957

27. Kim KM, Cho SK, Shin SH, Kim GT, Lee JH, Oh BJ, Kang KH, Hong JC, Choi JY, Shin JS, Chung YS (2005) Analysis of differentially expressed transcripts of fungal elicitor-and wound-treated wild rice (Oryza grandiglumis). J Plant Res 118(5):347-354. doi: 10.1007/s10265-005-0228-0

28. Kumar VV (2016) “Plant Growth-Promoting Microorganisms: Interaction with Plants and Soil”. In: Hakeem K, Akhtar M, Abdullah S (eds) Plant, Soil and Microbes. Springer, Cham. https://doi.org/10.1007/978-3-319-27455-3_1.

29. Lambardi M, Sharma KK, Thorpe TA (1993) Optimization of in vitro bud induction and plantlet formation from mature embryos of Aleppo pine (Pinus halepensis Mill.). In vitro Cell. Dev. Biol. 29: 189-199. https://doi.org/10.1007/BF02632034

30. Lavhale SG, Kalunke RM, Giri AP (2018) Structural, functional and evolutionary diversity of 4-coumarate-CoA ligase in plants. Planta 248(5):10631078. doi: 10.1007/s00425-018-2965-z

31. Lichtenthaler HK (1987) Chlorophylls and carotenoids: pigments of photosynthetic membranes. Methods Enzymol 148:350-382. https://doi.org/10.1016/0076-6879(87)48036-1

32. Liu CH, Di YP (2020) Analysis of RNA Sequencing Data Using CLC Genomics Workbench, in: Keohavong, P., Singh, K., Gao W. (Eds.), Molecular Toxicology Protocols, Methods in Molecular Biology, Vol 2102, Humana, New York, 2020

33. Liu W, Tang X, Qi X, Fu X, Ghimire S, Ma R, Li S, Zhang N, Si H (2020) The Ubiquitin Conjugating Enzyme: An Important Ubiquitin Transfer Platform in Ubiquitin-Proteasome System. International Journal of Molecular Science 21(8):2894. https://doi.org/10.3390/ijms21082894

34. Llorente BE, Larraburu EE (2013) In Vitro propagation of fraser photinia using Azospirillum-mediated root development, in: Lambardi M., (Eds.), Protocols for micropropagation of selected economically-important horticultural plants. Methods in Molecular Biology, Springer, Berlin, 2013, vol 11013, pp. 245258. doi: 10.1007/978-1-62703-074-8_19

35. Magoč T, Salzberg SL (2011) FLASH: fast length adjustment of short reads to improve genome assemblies. Bioinformatics 27(21):2957-2963. doi: 10.1093/bioinformatics/btr507

36. Mariette J, Noirot C, Klopp C (2011) Assessment of replicate bias in 454 pyrosequencing and a multi-purpose read-filtering tool. BMC Res Notes 4:149. https://doi.org/10.1186/1756-0500-4-149

37. Martínez-García E, de Lorenzo V (2011) Engineering multiple genomic deletions in Gram-negative bacteria: analysis of the multi-resistant antibiotic profile of Pseudomonas putida KT2440. Environ Microbiol 13(10):2702-2716. doi: 10.1111/j.1462-2920.2011.02538.x

38. Mazzucotelli E, Belloni S, Marone D, De Leonardis AM, Guerra D, Di Fonzo N, Cattivelli L, Mastrangelo AM (2006) The E3 ubiquitin ligase gene family in plants: regulation by degradation. Curr Genomics 7:509-522. doi: 10.2174/138920206779315728

39. Murashige T, Skoog F (1962) A Revised Medium for Rapid Growth and Bio Assays with Tobacco Tissue Cultures. Physiol Plantarum 15:473-497. https://doi.org/10.1111/j.1399-3054.1962.tb08052.x

40. Nakano M, lida K, Nyunoya H, lida H (2011) Determination of structural regions important for $\mathrm{Ca}^{2+}$ uptake activity in Arabidopsis MCA1 and MCA2 expressed in yeast. Plant Cell Physiol 52(11):1915-1930. doi: 10.1093/pcp/pcr131

41. Nishii K, Möller M, lida H (2021) Mix and match: Patchwork domain evolution of the land plant-specific Ca ${ }^{2+}$-permeable mechanosensitive channel MCA. Plos One. https://doi.org/10.1371/journal.pone.0249735. 15 April 2021

42. Nobori T, Cao Y, Entilla F, Dahms E, Tsuda Y, Garrido-Oter R, Tsuda K (2021) Dissecting the co-transcriptome landscape of plants and microbiota members. bioRxiv preprint. doi:https://doi.org/10.1101/2021.04.25.440543

43. Pertea M, Kim D, Pertea GM, Leek JT, Salzberg SL (2016) Transcript-level expression analysis of RNA-seq experiments with HISAT, StringTie and Ballgown. Nature Protocols 11(9):1650-1667. https://doi.org/10.1038/nprot.2016.095

44. Quesada MA, Tigier HA, Bukovac MJ, Valpuesta V (1990) Purification of an anionic isoperoxidase from peach seeds and its immunological comparison with other anionic isoperoxidases. Physiol Plant 79(4):623-628. doi: 10.1111/j.1399-3054.1990.tb00035.x

45. Quoirin M, Lepoivre P (1977) Improved media for in vitro culture of Prunus sp. Acta Hortic 78:437-442. https://doi.org/10.17660/ActaHortic.1977.78.54

Page $12 / 17$ 
46. Robert-Seilaniantz A, Grant M, Jones JD (2011) Hormone crosstalk in plant disease and defense: more than just jasmonate-salicylate antagonism. Annu Rev Phytopathol 49:317-343. doi: 10.1146/annurev-phyto-073009-114447

47. Rosenblueth M, Martínez-Romero E (2006) Bacterial Endophytes and Their Interactions with Hosts. Molecular Plant-Microbe Interactions. 19(8): 827-837. doi: 10.1094/MPMI-19-0827. PMID: 16903349

48. Ross S, Giglione C, Pierre M, Espagne C, Meinnel T (2005) Functional and developmental impact of cytosolic protein N-terminal methionine excision in Arabidopsis. Plant Physiol 137(2):623-637. 10.1104/pp.104.056861. doi

49. Sergiev I, Alexieva V, Karanov E (1997) Effect of spermine, atrazine and combination between them on some endogenous protective systems and stress markers in plants. Compt Rend Acad Bulg Sci 51:121-124

50. Sgherri CLM, Liggini B, Puliga S, Navari-Izzo F (1994) Antioxidant system in Sporobolus stapfianus: changes in response to desiccation and rehydration. Phytochemistry. 35 (1994) 561-565. https://doi.org/10.1016/S0031-9422(00)90561-2

51. Spiegel S, Scott SW, Bowman-Vance V, Tam Y, Galiakparov NN, Rosner A (1996) Improved detection of prunus necrotic ringspot virus by the polymerase chain reaction. European Journal of Plant Pathology 102:681-685. DOI:10.1007/BF01877249

52. Sturz AV, Christie BR, Nowak J (2000) Bacterial endophytes: potential role in developing sustainable systems of crop production. Critical Reviews in Plant Sciences 19:1-30. https://doi.org/10.1080/07352680091139169

53. Şah I, Akdemir H, Kaya E, Akkaya Ö, Özden Çiftçi Y (2019) The association of fraser photinia and its beneficial bacterium (PGB_invit) provided in vitro storage without subculture. Plant Cell, Tissue and Organ Culture (PCTOC). 136:605-615. 10.1007/s11240-018-01542-x

54. Tirandaz H, Dastgheib SMM, Amoozegar MA, Shavandi M, de la Haba RR, Ventosa A (2015) Pseudorhodoplanes sinuspersici gen. nov., sp. nov., isolated from oil-contaminated soil. Int J Syst Evol MicroBiol 65(12):4743-4748. doi: 10.1099/ijsem.0.000643

55. Wang SY, Jiao HJ, Faust M (1991) Changes in ascorbate, glutathione, and related enzyme activities during thidiazuron-induced bud break of apple. Physiol Plantarum 82:231-236. https://doi.org/10.1111/j.1399-3054.1991.tb00086.x

56. White JR, Roberts M, Yorke JA, Pop M (2008) Figaro: a novel statistical method for vector sequence removal. Bioinformatics 15(4):462-467. doi: 10.1093/bioinformatics/btm632. Epub 2008 Jan 17

57. Wu CH, Bernard SM, Andersen GL, Chen W (2009) Developing microbe-plant interactions for applications in plant-growth promotion and disease control, production of useful compounds, remediation and carbon sequestration. Microb Biotechnol 2(4):428-440. https://doi.org/10.1111/j.1751-

7915.2009.00109.x

58. Yuan S, Rong L, Chen S, Chen H, Zhang C, Chen L, Hao Q, Shan Z, Yang Z, Qiu D, Zhang X, Zhou X (2016) RNA-Seq analysis of differential gene expression responding to different rhizobium strains in soybean (Glycine max) roots. Front Plant Sci May 307:721. doi: 10.3389/fpls.2016.00721. PMID: 27303417; PMCID: PMC4885319

\section{Figures}

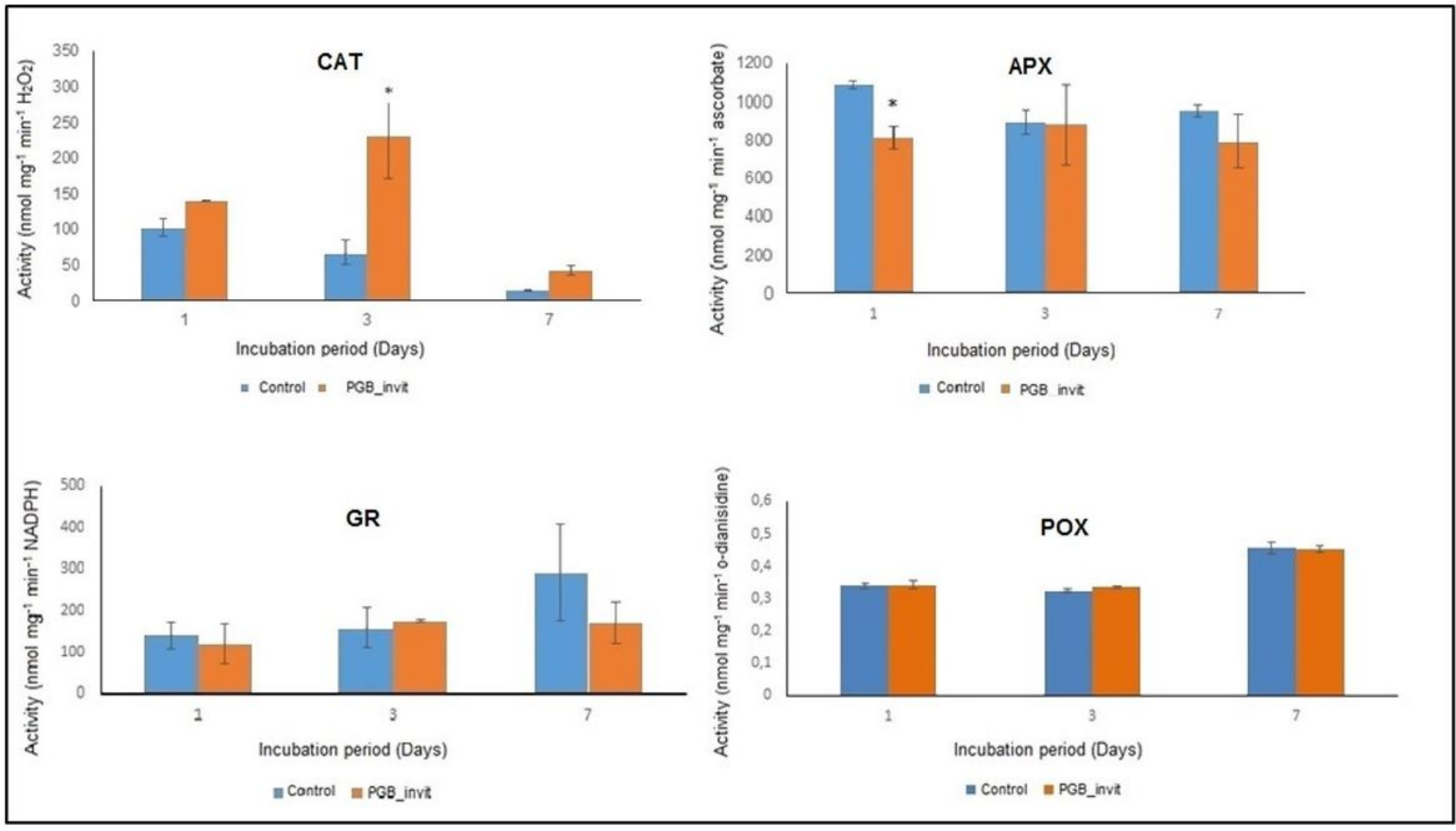

Page $13 / 17$ 


\section{Figure 1}

Antioxidant enzyme activities of control and active PGB_invit inoculated group. Catalase activity significantly increased in the $3^{\text {rd }}$ day and ascorbat peroxidase activity is significantly decreased in the $1^{\text {st }}$ day in active PGB_invit inoculated group.

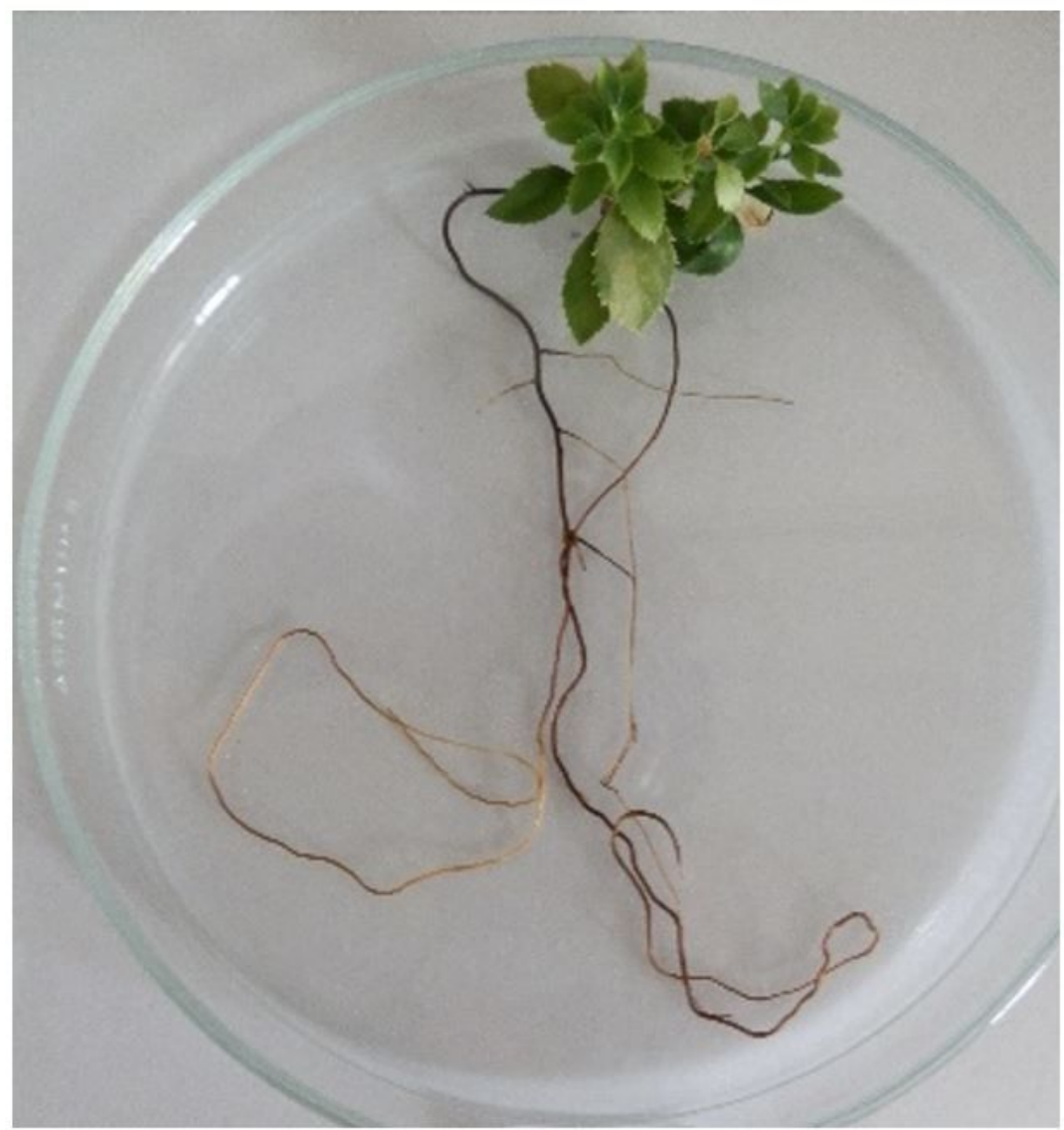

Figure 2

The rooting of microshoots inoculated with $10^{6} \mathrm{cfu} / \mathrm{ml} \mathrm{PGB}$ invit in $0.5 \mathrm{mg} / \mathrm{I}$ IBA supplemented medium. 


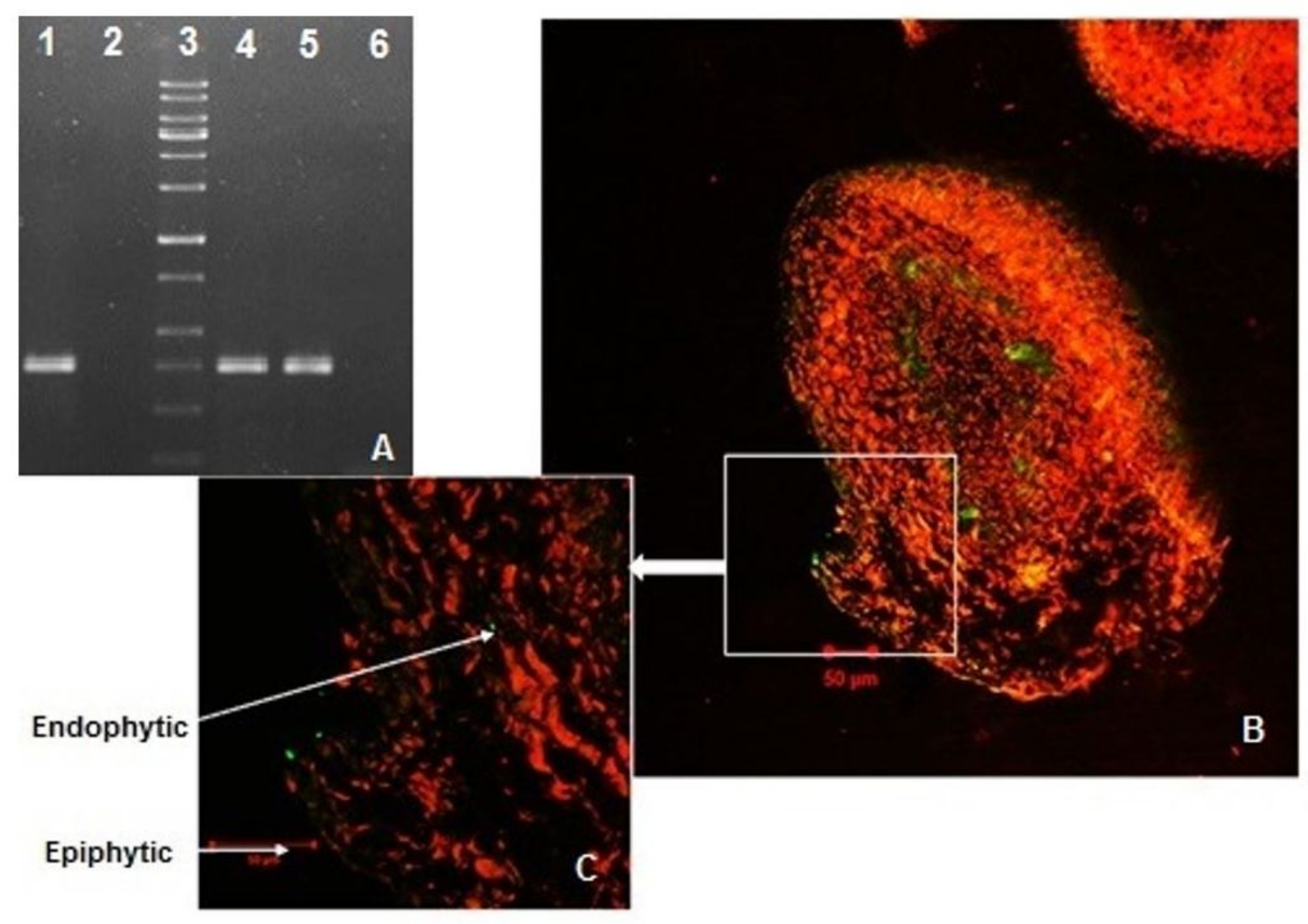

Figure 3

A.1\% agarose gel image after PCR amplification of transconjugants using aux and gfp primers 1. aux gene 750 bp, 2. negative control, 3. DNA ladder (1000 bp, Intron, 24074), 4. E. coli DH5a strain with pSEVA237-G plasmid containin gfp gene and 5. 750 bp gfp gene result obtained from the amplification of PGB_invit broth culture samples using aux primers, 6.negative control. B, C. Colonization of epiphytic and endophytic GFP-labeled PGB_invit in the cross sections of Fraser's Photinia. 


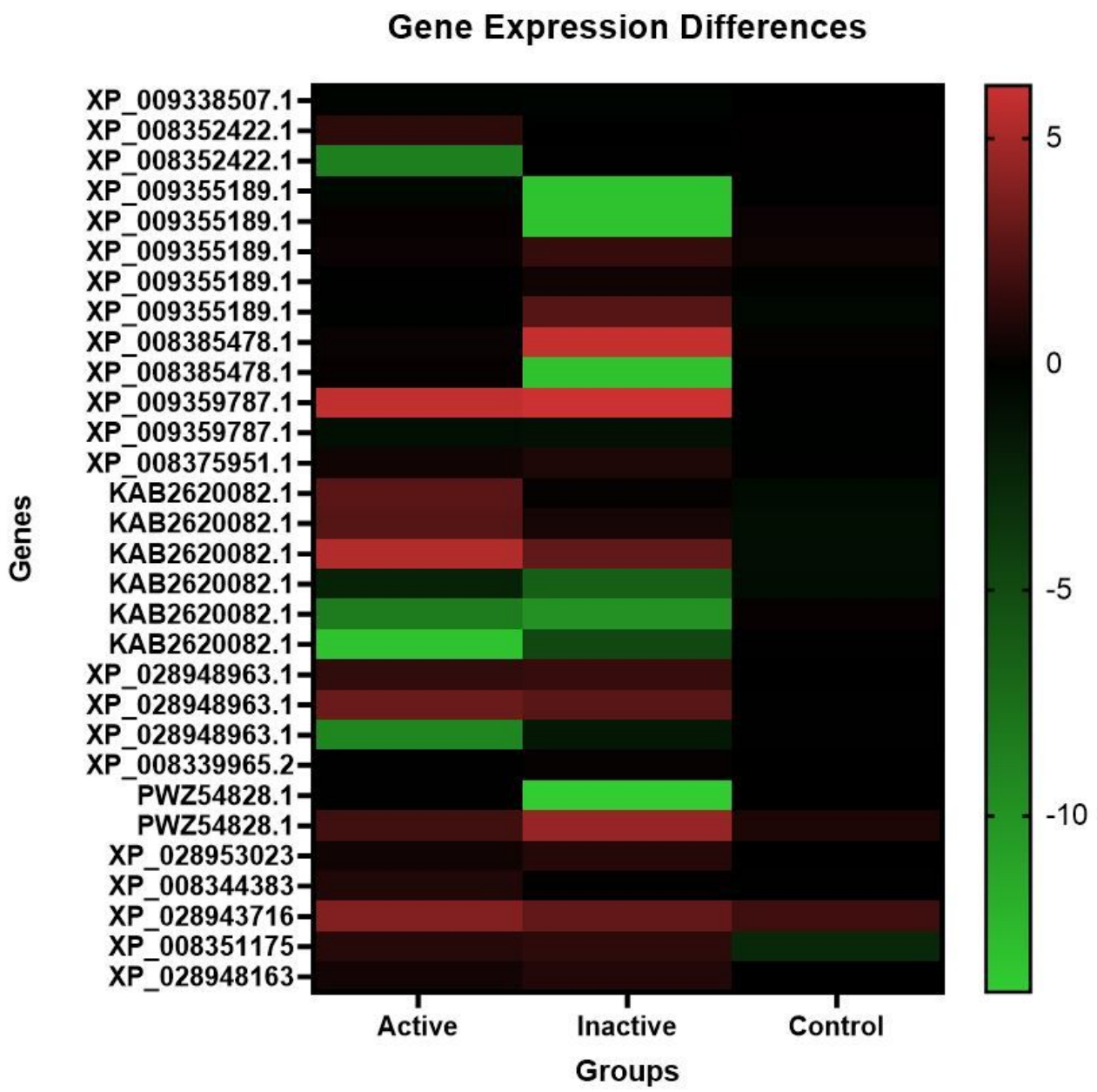

Figure 4

The heat map shows the differently expressed genes among control and PGB_invit (active and inactive) inoculated groups. The expression levels of genes are plotted as log2 (FPKM+1) for each sample to check for sample-specific deviations. The log conversion normalizes all data to a similar extent. In order to visualize the zero values in the graph, 1 is added to all log values. The up-regulated genes are indicated in red and down-regulated genes in green. The intensity of the color increases as the expression differences increase as shown in the bar at the right. 


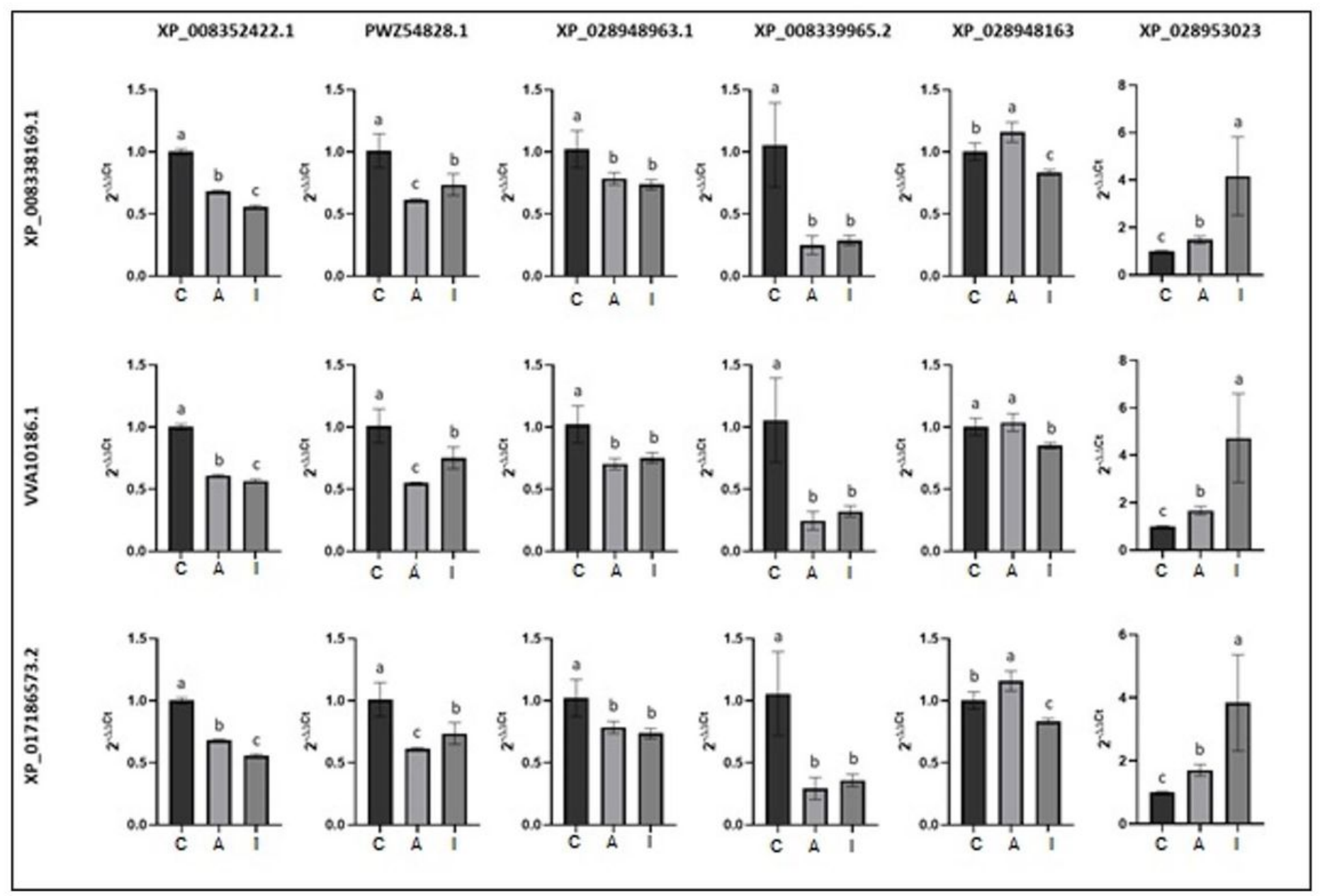

Figure 5

Expression results of genes whose gene expression was confirmed by qRT-PCR. XP_008338169.1, VVA10186.1 and XP_017186573.2 represent 3 different internal control gene, XP_008352422.1, PWZ54828.1, XP_028948963.1, XP_008339965.2, XP_028948163 and XP_028953023 represents the target genes. The expression levels of genes were converted to $2^{-\triangle \Delta C t}$ format compared to the control and presented using fold change values. C: Non-inoculated 60 days old photinia microshoots as control, A: $10^{6}$ active PGB_invit inoculated 60 days old photinia microshoots, I: $10^{6}$ inactive PGB_invit inoculated 60 days old photinia microshoots. Bars represent the standard error, and the different letters represent significant differences for each group $(P<0.05)$.

\section{Supplementary Files}

This is a list of supplementary files associated with this preprint. Click to download.

- SupFigure1.docx

- SupFigure2.docx

- SupTable1.docx

- SupTable2.docx

- SupTable3.docx

- SupTable4.docx

- SupTable5.docx

- SupTable6.docx

- SupTable7.docx

- SupTable8.docx 